\title{
Reply to comment(s) on "Emplacement history and evolution of the Deccan Volcanic Province, India, by Kale et al. (2020)" by K.S. Misra
}

\author{
${ }^{1}$ Advanced Center for Water Resources Development and Management (ACWADAM), Kshipra Society, Pune 411058, INDIA \\ ${ }^{2}$ Geological Survey of India (CR), SU: Maharashtra, Alandi Road, Pune 411006, INDIA \\ ${ }^{3}$ Department of Earth Sciences, Indian Institute of Technology (Bombay), Powai, Mumbai 400076, INDIA; \\ *Corresponding author, E-mail: dr.vivekale@gmail.com
}

(Received: September 17, 2020; Revised accepted: September 17, 2020)

https://doi.org/10.18814/epiiugs/2020/020083

We have read the 'Comment' on our paper by Dr. K.S. Mishra carefully, coming from a very senior geologist. We are thankful for his appreciation of our paper in the opening sentence. We note:

Except for the first three sentences, none of the contents have any commentary on our paper at all. Even here, Dr. Mishra appears to have either misunderstood or has misquoted us when he states that:

- "it reviews the chemo-stratigraphic work done in the western part of the Deccan..": our review covers the entire province and is not restricted to the western part!

- "The paper is also a step forward to remove certain... hot spot related volcanism during the northerly movement of Indian plate": we draw no such conclusion! In fact Fig. 1 (Inset) clearly depicts the linkage between the Reunion and Deccan.

The remaining lengthy text and figures have no reference or relevance to our paper at all. It is only a compilation that seeks to highlight his own publications and tries to justify them speciously. For example:

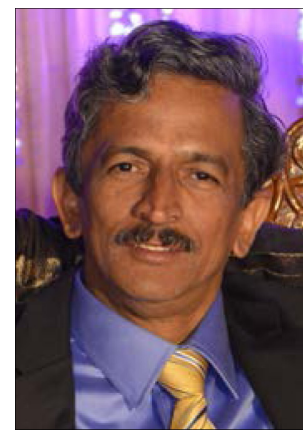

Vivek S. Kale obtained M.Sc. (Geology) degree from the University of Pune (since renamed as the Savitribai Phule Pune University) in 1981; and Ph.D. degree in 1985 under the guidance of Prof. V.V. Peshwa. He was on the faculty of the Geology Department of University of Pune between 1987 and 1999; before taking up an entrepreneurial role with the Kalyani Group of Industries and leading the Geospatial business. He also served as an Adjunct Professor of Earth Sciences (2015 - 2017) at the Indian Institute of Technology Bombay. He is one of the founders and currently Managing Trustee \& Treasurer of a not-for-profit organisation ACWADAM, Pune. His primary research interests are in the fields of (a) Proterozoic sedimentary basins and (b) the Deccan Traps and large igneous provinces.
- The clubbing together of 'extension' and 'rifting' (e.g. Paleozoic to Mesozoic Gondwana basins, Proterozoic Kaladgi and Bhima basins) events that are temporally and spatially independent of each other cannot justify any connection to 'Cretaceous magmatism'. Yet, Dr. Misra fallaciously seeks to put them into one single box!

- While putting all Cretaceous volcanic activity from the Indian subcontinent into a 'single' window, Dr. Mishra appears to conveniently forget an equally large body of Cretaceous magmatic activity in the Himalayan and off-shore and marine segments of the Indian Ocean - Arabian Sea - Bay of Bengal. What more, they are individual magmatic events with diverse tectonic settings; spread across the entire 81 million year span of the Cretaceous ( $145 \mathrm{Ma}-66 \mathrm{Ma})$ ! The absurd 'conclusion' of combining them into one event is scientifically untenable.

In absence of any specific queries / observations / critique on our paper, we cannot provide any relevant or significant response to this "Comment".

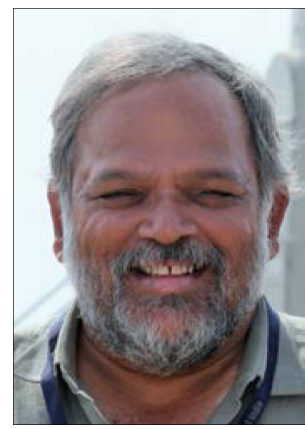

Makarand Bodas one of the pioneering contributors to the 'Chemostratigraphy' of the western Deccan Province, did his M.Sc from the Department of Geology, University of Pune in 1983 and obtained his $\mathrm{PhD}$ in Earth Sciences from the Indian Institute of Technology Bombay, Powai, Mumbai under the guidance of Prof. K.V. Subbarao, in 1991. He has been working for the Geological Survey of India for more than 30 years (from 1989) and is presently heading the Division of Volcanology. His work experience and research interests include the study of Deccan lavas, slope failures in the Deccan Volcanic Province and geology of Bundelkhand craton. 


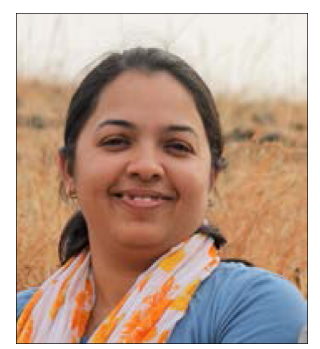

Poushali Chatterjee received her M. Sc. in geology from Ranchi University in 2008 and M. Tech. in Remote Sensing from Birla Institute of Technology (BIT), Mesra, Ranchi in 2011. She is currently a senior geologist with the Geological Survey of India in the Division of Volcanology, at Pune. She is engaged in study of the western Deccan lava pile with the objective of (a) developing 3D architecture of the Deccan lavas and (b) towards the elucidation of the stratotypes of formations the Deccan Volcanic Province.

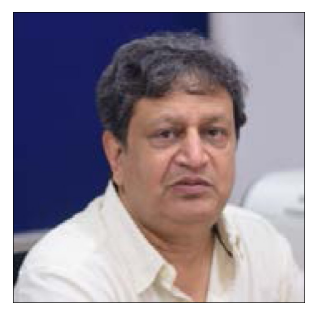

Kanchan Pande obtained M.Sc. (Geology) degree from the Kumaun University, Nainital in 1981, Ph.D. degree in 1990 under the guidance of Prof. K. Gopalan from Physical Research Laboratory (PRL), Ahmedabad (awarded by Gujarat University, Ahmedabad). He is currently a Professor at the department of Earth Sciences at IIT Bombay, Mumbai. His primary research interests are in the fields of (a) geochronology of Deccan Volcanic Province and (b) geo- and thermochronology of collisional tectonics. 